\title{
Pendidikan Karakter di Lingkungan Keluarga Selama Pembelajaran Jarak Jauh pada Masa Pandemi COVID-19
}

\author{
I Putu Yoga Purandina1, I Made Astra Winaya ${ }^{2}$ \\ 1Sekolah Tinggi Agama Hindu Negeri Mpu Kuturan Singaraja \\ 2Universitas Dwijendra \\ 1yogapurandina@stahnmpukuturan.ac.id,2winaya@undwi.ac.id
}

DOI : $10.37329 /$ cetta.v3i2.454

\begin{tabular}{l}
\hline Keywords: \\
\hline Character \\
Education; \\
Learning from \\
Home; COVID-19 \\
\hline
\end{tabular}

\begin{abstract}
COVID-19 provides a bad life for human life. All activities become inhibited and limited. Similarly in the field of education. Students must learn and do their activities at home. But this can be a good development for the development of the character of education in Family Environment. Thus the purpose of this research is to study whether research studies while at home are accompanied by parents who are able to develop character education, that is the first. Second, to find out what character values can be developed during learning at home. Third, to find out the cause of developing with these character values. This study used qualitative research method. With case studies on kindergarten and elementary school students in Kecamatan Marga. Data obtained by distributing questionnaires to students, parents and teachers through the Whatsapp group of teachers and parents of students. Also strengthened by interview data on students, parents and teachers. The results showed differences in the development of character education and the relationship between children and parents that were quite good during learning from this house. Character values that can be developed from activities carried out by students at home are (1) Religious, (2) Disciplinary, (3) Creative, (4) Independent, (5) Responsibility, and (6) Curiosity. The development of these character values is the result of the synergy of teachers and parents in guiding students with gratitude, engaging, carrying out positive activities together in this COVID-19 pandemic.
\end{abstract}

\begin{tabular}{lll}
\hline Kata Kunci: & Abstrak \\
\cline { 1 - 1 } $\begin{array}{l}\text { Pendidikan } \\
\text { Karakter; Belajar }\end{array}$ & $\begin{array}{l}\text { COVID-19 memberikan dampak yang buruk bagi kehidupan } \\
\text { dari Rumah; }\end{array}$ & $\begin{array}{l}\text { Begitu pula di bidang pendidikan. Siswa harus belajar dan } \\
\text { COVID-19 }\end{array}$ \\
\cline { 1 - 1 } & $\begin{array}{l}\text { melakukan aktivitasnya di rumah. Namun hal ini bisa menjadi } \\
\text { situang baik untuk pengembangan pendidikan karakter } \\
\text { di lingkungan keluarga. Dengan demikian tujuan penelitian }\end{array}$ \\
\hline
\end{tabular}


ini adalah untuk mengetahui apakah aktivitas belajar siswa selama di rumah ditemani oleh orang tua mampu mengembangkan pendidikan karakter, itu yang pertama. Kedua, untuk mengetahui nilai-nilai karakter apa saja yang bisa berkembang selama pembelajaran di rumah. Ketiga, untuk mengetahui penyebab berkembang dengan baiknya nilai-nilai karakter ini. Penelitian ini menggunakan metode penelitian kualitatif. Dengan studi kasus pada siswa TK dan SD se-Kecamatan Marga. Data diperoleh dengan cara menyebar kuisioner kepada siswa, orang tua dan guru melalui group Whatsapp guru dan orang tua siswa. Diperkuat juga dengan data wawancara terhadap siswa, orang tua dan guru. Hasil penelitian ini menunjukkan adanya perkembangan pendidikan karakter dan hubungan anak dan orang tua yang cukup baik selama pembelajaran dari rumah ini. Adapun nilai-nilai karakter yang mampu dikembangkan dari aktivitas yang dilakukan siswa di rumah yaitu (1) Nilai karakter religius, (2) Nilai karakter disiplin, (3) Nilai karakter kreatif, (4) Nilai karakter mandiri, (5) Nilai karakter tanggung jawab, dan (6) Nilai karakter rasa ingin tahu. Berkembangnya nilainilai karakter ini merupakan hasil sinergitas guru dan orang tua dalam membimbing siswa dengan penuh kasih saying, berinteraksi, melakukan aktivitas yang positif bersama-sama dalam pandemi COVID-19 ini.

\section{Pendahuluan}

Corona Virus Disease (COVID-19) sangat meresahkan masyarakat dunia selama dua bulan terakhir ini. Wabah ini disebabkan oleh Novel Coronavirus (SARS-Cov-2) (World Health Organization, 2020a). Sebelumnya penyakit jenis ini sama sekali belum pernah terdeteksi dalam dunia medis. Wabah ini memang pertama kali dilaporkan mewabah di Wuhan, China. Virus ini berkembang dengan cepat menginfeksi manusia melalui sistem pernafasan. Per April 2020, sekitar 1.8 juta jiwa terinfeksi oleh virus ini dan sekitar ratusan ribu jiwa tersebut tidak mampu bertahan terhadap virus tersebut atau mengalami kematian di sekitar 213 negara di dunia (World Health Organization, 2020b).

COVID-19 merupakan penyakit yang tegolong baru dimana penyebab, asal muasal virus ini belum diketahui secara pasti (Chan dkk, 2020). Virus ini sangatlah berbahaya, sangat mudah menular terhadap sesama manusia. Penularan (transmission) virus ini terjadi melalui kontak yang dekat antar individu yang mana salah satu individu telah terinfeksi sebelumnya, kemudian mengeluarkan menyipratkan tetesan 
pernafasan (droplet) dari batuk dan bersin (Ghinai, 2020). Ketahanan virus ini lumayan kuat, mampu bertahan selama tiga hari dengan plastic atau stainless steel dan dalam aerosol selama tiga jam. Bahkan belakangan ditemukan pula pada feses, namun belum diketahui apakah penularan melalui feses bisa terjadi (Tim Kerja Kementerian Dalam Negeri, 2020).

Paru-paru menjadi organ yang paling diserang oleh virus ini, karena virus mengakses sel inang melalui enzim tertentu yang terdapat pada bagian sel alveolal tipe II paru-paru. Masa inkubasi virus ini ditenggarai terjadi sekitar 1-14 hari, yang secara umum terjadi di hari ke-3 dan ke-7 (Isbaniah, 2020). Gejala utama yang ditimbulkan adalah demam, kelelahan, batuk kering dan juga terdapat gejala lain, seperti hidung tersumbat, pilek, pharyngalgia, myalgia, dan diare. Bahkan bisa terjadi sampai ke yang lebih parah seperti sindrom gangguan pernafasan akut, syok septik, disfungsi perdarahan, batuk serta kegagalan banyak organ. Orang tua sangat rentan bisa sampai ke tahap yang lebih parah karena membawa penyakit bawaan lain (Saxena, 2020).

Begitu berbahayanya penyakit ini, sehingga pemerintah berupaya keras untuk menanggulangi penyebaran COVID-19 ini. Sampai saat ini belum ditemukannya obat serta vaksin untuk masalah ini sehingga jalan satu-satunya hanyalah memutus mata rantai penyebaran COVID-19 ini. Cara yang paling ampuh untuk memutus rantai penyebaran wabah ini adalah dengan melakukan pembatasan sosial (sosial distancing) dan pembatasan fisik (physical distancing) (Tim Kerja Kementerian Dalam Negeri, 2020). Pembatasan sosial ialah menjaga jarak dalam bersosialisasi, menjaga jarak dalam melakukan aktivitas sosial, termasuk membatasi diri untuk melakukan sosialisi di masyarakat meminimalisir kotak dengan individu yang lain. Begitu pula pembatasan fisik maksudnya ialah pembatasan dengan menjaga tubuh secara fisik dengan jarak 1-2 meter ketika melakukan kontak atau bersinggungan dengan individu lainnya. Disamping itu pola hidup bersih dan sehat juga sangat penting untuk memutus mata rantai penyebaran virus ini seperti selalu menggunakan masker, rajin mencuci tangan, dll (Zhou, 2020).

Untuk mengatur hal tersebut pemerintah telah dengan tegas mengeluarkan berbagai kebijakan di segala bidang (Suharyanto, 2020). Di bidang kesehatan, pemerintah telah mengeluarkan kebijakan mengenai pembatasan sosial berskala besar (PSBB) dan penerapan perilaku hidup bersih dan sehat (PHBS). Di bidang pendidikan kementerian pendidikan telah mengeluarkan surat edaran mengenai pembelajaran 
dari rumah (Learning from Home) (Sekretaris Kabinet, 2020). Begitu pula di bidang lainnya juga telah diatur tentang pembatasan dan kebijakan terbaik supaya terhindar dari pademi ini. Sangat miris memang, namun inilah yang saat ini bias dilakukan. Terutama di bidang pendidikan, siswa terpaksa harus belajar dari rumah dengan melakukan pola pembelajaran jarak jauh (Remote Teaching) (Kementerian Pendidikan dan Kebudayaan, 2020).

Pembelajaran jarak jauh (PJJ) ini sebenarnya tidak mudah dilakukan, berbeda hampir 80 derajat dengan pembelajaran tatap muka (face to face). Perbedaan yang paling mendasar tentu siswa tidak bisa melakukan interaksi langsung dengan guru (Teguh, 2015). Sehingga komunikasi yang terjalin sangatlah terbatas. Keterbatasan komunikasi menyebabkan terjadinya pemerolehan informasi dan intruksi dari guru sangatlah terbatas. Memang pembelajaran jarak jauh seyogyanya menitik beratkan pada kemandirian siswa (Diana dkk, 2020). Kemandirian inilah yang nantinya harus dipupuk di dalam pandemi ini. Tentu pembelajaran ini akan memiliki keunggulan dan kelemahan. Keunggulannya, siswa akan lebih fleksibel dalam belajar, tidak mesti harus on time, dan tempatnyapun bisa dikondisikan tergantung situasi dan kondisi. Siswa juga akan lebih leluasa menentukan atau mencari sumber belajarnya sendiri bisa mengakses internet dll. Namun kelemahannya, siswa tidak dapat bersosialisasi dengan siswa lainnya dan gurunya secara nyata, sehingga akan mempengaruhi emosional siswa itu sendiri. Disamping itu, siswa harus bergantung dengan jaringan internet jika pembelajaran jarak jauh yang dilakukan berbasis dalam jaringa internet (daring) (Nazerly, 2020).

Nah inilah kondisi yang dialami siswa sekarang ini. Siswa lebih banyak berinteraksi di rumah. Sebenarnya pembelajaran jarak jauh yang dilakukan oleh siswa di rumah selama pandemi ini tidaklah sepenuhnya menjadi buruk (Abdussomad, 2020). Seperti halnya yang telah dipaparkan tadi, bahwa ada sikap karakter positif siswa yang mungkin bisa tumbuh di dalam dirinya selama pembelajaran jarak jauh dari rumah ini. Salah satunya yaitu kemandirian. Karakter nerupakan hal yang hakiki dimiliki oleh setiap orang. Karakter juga menjadi ciri setiap individu yang satu dengan individu yang lainnya (Sudrajat, 2011). Bahkan karakter membedakan manusia dengan makhluk hidup lainnya. Pemahaman terhadap karakter memang relatif dan berbedabeda bagi setiap ahli. Menurut Sjarkawi karakter merupakan kepribadian atau ciri yang mencirikan seseorang yang didapatkan melalui proses pembentukan dalam lingkungan hidupnya (Kusuma, 2010). 
Karakter sangat dipengaruhi oleh lingkungan dimana individu ini berkembang. Walaupun karakter bisa juga dipengaruhi oleh faktor bawaan, namun hal itu persentasenya sangatlah kecil. Seorang anak yang tumbuh dan berkembang di lingkungan moral yang baik, tentu akan menjadi anak yang memiliki moral yang baik, begitu pula sebaliknya. Karakter tidak muncul begitu saja, namun berproses dari lingkungan yang dikontruksikan secara terus menerus secara simultan. (Lickona, 2012). Ahmadi (2017) menyatakan bahwa karakter bisa dibentuk dan dikondisikan oleh seseorang. Dalam hal ini bisa dikondisikan oleh guru di sekolah dan para orang tua di rumah serta lingkungan masyarakat. Namun yang paling memiliki peranan di sini tentu Guru dan orang tua di rumah. Guru dan orang tua mempunyai peran yang vital dalam pembentukan karakter anak (Wulandari \& Kristiawan, 2017). Guru dan orang tua harus menyediakan atau mengkondisikan wadah yang subur sebagai tempat penyemaian nilai-nilai karakter yang nantinya dapat membentuk setiap individu memiliki pembeda yang mencirikan dan memiliki perilaku moral yang baik.

Memang sebenarnya lingkungan keluarga merupakan lingkungan yang baik dalam mengembangkan sikap atau karakter positif siswa. Keluarga merupakan lingkungan awal seorang anak melakukan interkasi, mengalami tumbuh kembang secara fisik dan emosinya (Hulukati, 2015). Selama ini juga sesungguhnya siswa lebih banyak berinteraksi di rumah, walaupun selama ini mata kita seakan hanya fokus terhadap pendidikan dalam hal ini pengembangan karakter anak di sekolah. Tetapi di rumah semestinya menjadi tempat yang baik dan bahkan lebih baik untuk melakungan pengembangan sikap karakter tersebut. Interaksi ini akan membentuk pola yang baik, mengakrabkan para anggota keluarga dengan berkomunikasi secara intens, sehingga memiliki quality time yang baik pula (Prasetiawan, 2016). Di sinilah orang tua mempunyai banyak waktu dalam membentuk anaknya agar memiliki karakter yang baik dan kuat. Tentu orang tua harus menjadi seorang pendidik, menggantikan guru di sekolah, mengambil peran yang sentral sebagai life educator di rumah selama masa pandemi ini. Inilah saatnya kondisi yang baik ini diharapkan menjadi momentum penanaman hal yang positif bagi anak (Anwar, 2013).

Pemerintah telah mengeluarkan Peraturan Presiden Nomor 87 tahun 2017 tentang penguatan Pendidikan Karakter. Tujuan dari Perpres ini tentu untuk membentuk pribadi bangsa yang berbudaya melalui penguatan nilai-nilai karakter yang digali dari budaya bangsa Indonesia sendiri. Penguatan Pendidikan Karakter 
yang disingkat PPK ini adalah merupakan upaya pemerintah di bawah satuan pendidikan untuk memeperkuat karakter peserta dididk melalui harmonisasi olah hati, olah pikir, olah raga, melibatkan tiga satuan pendidikan yaitu sekolah, keluarga dan masyarakat. Kemudian ditindaklanjuti dengan Permendikbud Nomor 20 Tahun 2018 tentang Penguatan Pendidikan Karakter (PPK), memperkuat pendidikan karakter yaitu dengan melaksanakan pendidikan karakter yang berdasar asas Pancasila dengan menanamkan sikap religious, jujur, toleran, disiplin, bekerja keras, kreatif, mandiri, demokratis, rasa ingin tahu, semangat kebangsaan, cinta tanah air, menghargai prestasi, komunikatif, cinta damai, gemar membaca, peduli lingkungan, peduli sosial, dan bertanggung jawab. Semua sikap tersebut merupakan penjabaran dari 5 (lima) nilai pokok yaitu religiusitas, nasionalisme, kemandirian, gotong royong, dan integritas.

Di sekolah, penguatan pendidikan karakter ini telah dilakukan dengan baik yaitu dengan menyelipkan nilai-nilai karakter ini pada setiap aktivitas pembelajaran (Dalyono \& Lestariningsih, 2016). Namun hal ini tidak akan berjalan maksimal karena semestinya pendidikan karakter harus melibatkan semua aspek lingkungan secara garis besar yaitu sekolah, keluarga, dan masyarakat (Supranoto, 2015). Di masyarakat pola pendidikan karakter ini sebenarnya telah dilakukan melalui aturan norma serta kearifan lokal yang berlaku di masyarakat, sehingga setiap individu akan dibatasi dan dilurskan oleh aturan norma serta kearifan lokal tersebut sehingga menjadi terbiasa dalam sikap karakter yang sesuai dan diterima di masyarakat itu sendiri (Ruyadi, 2010). Sedangkan pendidikan karakter di lingkungan keluarga merupakan pendidikan karakter terbaik yang bisa dilakukan. Namun, selama ini usaha optimalisasi pendidikan karakter di lingkungan keluarga ini kurang maksimal atau belum dikonsep dengan baik (Syarbini, 2014). Karena kurangnya kesadaran orang tua dalam pendidikan karakter untuk ananknya, kesibukan orang tua, dan ketidaktahuan orang tua bagaimana cara membentuk karakter anak yang baik (Muslikhin, 2019).

Inilah momentum yang baik bagi semua pihak, baik guru dan orang tua untuk memngembangkan pendidikan karakter anak. Saat ini 24 jam anak berada di rumah, sehingga sangat tepat guru dan orang tua berkolaborasi mendesain pola pendidikan karakter yang baik selama pembelajaran jarak jauh di rumah ini. Kualitas komunikasi orang tua dan anak yang semakin baik akan meningkatkan kepercayaan anak terhadap orang tuanya (Badudu, 2019). Di sinilah seharusnya orang tua mengambil peran 
sebagai pendidik karakter yang handal. Pendidikan karakter di lingkungan keluarga harus bisa dioptimalkan dalam kondisi ini. Jangan dibiarkan terlewat begitu saja. Inilah momentum yang baik untuk menebar benih karakter tersebut. Wadah atau tempat penyemaian sudah cukup baik tinggal bagaimana cara menyemainya. Tentu tidak semua orang tua paham akan hal itu. Disamping itu, sangat diperlukan bantuan guru di sekolah untuk tetap melakukan sinergitas dengan para orang tua selama pandemi ini.

Maka dari itu penulis ingin lebih jauh mengetahui tentang bagaimana tumbuhnya pendidikan karakter di dalam lingkungan keluarga selama pembelajaran jarak jauh dari rumah ini. Nilai-nilai karakter apa yang bisa tumbuh dalam diri siswa selama pembelajaran jarak jauh dari rumah ini. Serta, mengapa nilai-nilai karakter tersebut mampu tumbuh dalam diri siswa selama pembelajaran jarak jauh dari rumah ini. Penelitian ini dilakukan terhadap anak, orang tua, dan guru TK dan SD di Kecamatan Marga, Kabupaten Tabanan, Provinsi Bali. Penelitian ini diharapkan mampu menggambarkan pendidikan karakter di lingkungan keluarga selama pembelajaran dari rumah selama pandemi COVID-19, khususnya untuk siswa TK dan SD di Kecamatan Marga, Kabupaten Tabanan, Provinsi Bali.

\section{Metode}

Desain peneltian yang digunakan pada penelitian ini adalah penelitian kualitatif. Penelitian kualitatif fokus terhadap investigasi kualitas hubungan, aktifitas, situasi, dan material (Fraenkel and Wallen, 2008). Penelitian ini merupakan penelitian diskriptif kualitatif dimana seting tempat kondisi dan situasinya sebagai data langsung, serta peneliti memiliki peran sentral sebagai kunnci dari keseluruhan instrument yang ada (Key Instrument) (Gerring, 2007). Lebih lanjut, Nunan (1992) menyatakan bahwa penelitian jenis deskriptif kualitatif ini sangat cocok untuk menginvestigasi orang, kejadian, kelompok orang, serta institusi tertentu.

Dalam penelitian ini penulis menganalisis tentang Pendidikan Karakter yang Tumbuh Subur selama Pendidikan Jarak Jauh dari Rumah pada Pandemi COVID-19. Adapun data yang digunakan yaitu hasil dari pengisian questionnaire yang disebar melalui Whatsapp Group guru wali kelas dan orang tua siswa TK dan SD se-kecamatan Marga, Kabupaten Tabanan, Provinsi Bali. Adapun data yang diperoleh merupakan kegiatan-kegiatan yang dilakukan oleh orang tua dengan anaknya di rumah, nilai-nilai 
karakter yang bisa tumbuh dari kegiatan tersebut, intruksi dari guru atau pembelajaran yang didesain oleh guru selama siswa belajar dari rumah. Ditambah pula dengan hasil wawancara terhadap beberapa siswa, orang tua, dan orang tua secara acak.

Peneliti dalam penelitian ini adalah sebagai intrumen utama. Peneliti mennganalisis data yang diperoleh melalui kuisioner yang disebar melalui group Whatssapp para guru wali dengan orang tua. Kuisioner ini dibuat menggunakan google form yang dibuat dan telah divalidasi oleh para ahli. Di samping itu digunakan pula daftar wawancara (Interview Guide) untuk mempermudah melakukan interview terhadap siswa, orang tua, dan guru. Semua instrument ini merupakan instrument yang tepat dan sesuai untuk mengadakan metode penelitian deskriptif kualitatif. Memang untuk mencapai tujuan penelitian seperti ini harus dibantu dengan instrument ketika mengobservasi dan memperoleh data (Heigham dan Croker, 2009).

Untuk mendapatkan data yang pas dan sesuai, maka harus mendapatkan data yang reliabel dan valid. Data yang diperoleh harus dilakukan pengecekan silang dan berulang sehingga menemukan data yang sahih yang sering disebut sebagai Triangulasi Data (Moleong, 2013). Campbell dan Fiske dalam Roulston (2018) menambahkan bahwa Triangualasi merupakan sebuah pendekatan atau cara untuk memperoleh data yang akurat dengan menggunakan strategi pengambilan data yang berbeda-beda atau kombinasi. Selain itu dilakukan juga Thrustworthiness dalam penelitian ini, yang fokus pada empat aspek seperti, data, transkripsi data, teknik pengambilan data, dan temuan.

Ada dua metode atau strategi utama dalam pengumpulan data, yaitu pengambilan data menggunakan kuisioner dan interview. Kuisioner yang dibuat menggunakan google form, dan disebar melalui group Whatssapp guru wali kelas dengan orang tua siswa. Kuisioner tersebut terdiri dari dua jenis, yaitu kuisioner untuk orang tua dan siswa, serta kuisioner untuk guru. Isian kuisioner tersebut berupa pertanyaan tetntang kegiatan yang sering dilakukan antara anak dan orang tua, seberapa sering dilakukan, bagaimana melakukannya, dan apakah menyenangkan atau tidak. Begitu juga kuisioner untuk guru, berisi kegiatan apa yang diintruksikan oleh guru untuk dilakukan oleh siswa di rumah untuk pengembangan pendidikan karakternya siswa, nilai-nilai karakter apa yang dapat ditumbuhkan dalam kegiatan tersebut. Untuk pengambilan data melalui interview dilakukan secara acak melalui 
virtual meeting karena masih dalam keadaan pandemi COVID-19. Di dalam interview ini lebih menggali informasi yang lebih dalam yang berisi pertanyaan open-ended mengenai narasi langsung mengenai kegiatan yang telah dilakukan bersama anaknya, serta pendapat dan saran mereka terhadap kegiatan pendidikan karakter ini. Interview terhadap guru juga dilakukan seperti demikian, namun berisi pertanyaan tentang kegiatan belajar, dan nilai karakter yang ditumbuhkan, serta pendapat dan sarannya pula.

Analisis data yang dilakukan berdasarkan pendekatan Miles-Huberman, yang terdiri dari tiga konsep yaitu reduksi data (data reduction) yang telah dilakukan langsung pada saat pengumpulan data, kedua adalah penyajian data (Data Display), dan verifikasi gambarran kesimpulan (Milles-Huberman pada Sugiono (2019). Pendekatan analisis ini merupakan aktivitas yang secara langsung dalam dalam proses investigasi tersebut. Begitu data diperoleh akan langsung dianalis sebagi bentuk proses investigasi. Menganalisis data di sini, dilakukan dengan cara interaktif dan simultan sampai semua masalah dalam penelitian ini terjawab atau didapatkan pemecahannya. Reduksi data dilakukan dengan sangat berhati-hati dimana hanya mengambil data yang diperlukan saja sesuai reseach problem. Data yang dimaksudnya tentunya yang sesuai dengan pendidikan karakter yang tumbuh selama pendidikan jaraj jauh dari rumah pada pandemi COVID-19. Selain data tersebut akan disampingkan atau dengan kata lain dibuang.

Data yang dipeorleh akan ditampilkan secara tahap demi tahap, yaitu dipaparkan dalam betuk kalimat baik secara deduktif dan induktif. Termasuk juga data analisisnya dipaparkan secara bertahap, berdasarkan tahapan research questions untuk mendapatkan narasi yang baik dan jelas untuk menjelaskan pendidikan karakter selama pembelajaran jarak jauh dari rumah pada pandemi COVID-19 ini.

\section{Hasil dan Pembahasan}

Berlakunya Peraturan Mernteri Pendidikan dan Kebudayaan Indonesia No. 4 Tahun 2020 tetnang pembelajaran jarak jauh guna mencegah penyebaran Covid-19, mengisyaratkan pembelajaran yang mengkolaborasikan peran guru, siswa dan orang tua dalam proses pembelajaran. Selain itu, di masa pandemi covid-19 sekarang ini, kebijakan pemerintah dalam menerapakan social distancing bagi seluruh mayarakat menyebabkan segala kegaiatan di luar rumah di kurangi dan pekerjaan dilakukan dari 
rumah (work from Home). Tentu hal ini membuat waktu bersama keluarga di rumah menjadi lebih banyak dan wajib dimanfaatkan dengan baik. Dari kaca mata pendidikan, dimasa pandemi seperti sekarang ini adalah kesempatan baik untuk orang tua terlibat secara langsung dalam proses pembelajaran anaknya. Peran orang tua dalam pembelajaran memiliki peranan yang sangat startegis dalam pencapaian tujuan pembelajaran yang hendak dicapai.

Pelaksanaan pembelajaran jarak jauh yang melibatkan orang tuan dalam proses pembelajarannya diharapakan mampu menekankan pembentukan nilai-nilai karakter bagi siswa. Pengukuran terhadap pengembangan nilai-nilai karakter anak selama pandemi Covid-19 dilakukan menggunakan kuesioner yang di buat dalam aplikasi google form sebagai instrumen pengumpulan data penelitian. Berdasarkan hasil pengisian kuesioner melalui google form yang di sebar oleh wali kelas di masingmasing sekolah TK dan SD di Kecamatan Marga memalalui Media WhatsApp Grup wali siswa, diperoleh data lima nilai-nilai karakter yang dominan di kembangkan selama pandemi covid-19 adalah sebagai berikut.

\section{Menumbuhkan Nilai-nilai Karakter Relegius}

Menurut Badan Penelitian dan Pengembangan, Pusat Kurikulum Kementrian Pendidikan Nasional (2010) menjelakan Religius: merupakan sikap dan perilaku yang patuh dan melaksanakan ajaran agama yang dianutnya, toleren terhadap pelaksanaan ibadah agama lain, dan hidup rukun dengan pemeluk agama lain. Salah satu strategi atau metode yang dipergunakan dalam membentuk karakter religius adalah dengan pembentukan kebiasaan yang baik dan meninggalkan yang buruk melalui bimbingan, latihan dan kerja keras. Pembentukan kebiasaan tersebut akan menjadi sebuah karakter seseorang. Maka karakter yang kuat biasanya dibentuk oleh penanaman nilai yang menekankan tentang baik dan buruk. Nilai ini dibangun melalui penghayatan dan pengalaman. Pembentukan karakter relegius terhadap anak dapat dilakukan jika seluruh stake holders pendidikan termasuk orang tua dan keluarga ikut berpartisipasi dan beperan serta.

Dari hasil Kuesioner yang diisi dalam aplikasi Google Form yang telah sebar melalui grup WhatsApp orang tua siswa, sebanyak 201 orang dari 219 responden menyatakan bahwa dalam pikiran, perkataan, dan tindakannya mengupayakan berdasarkan pada nilai-nilai ketuhanan atau agama. Pada masa pandemi Covid-19 ini, 
orang tua selalu melibatkan anaknya untuk ikut melakukan persembahyangan, sebagai upaya selalu memohon kepada Tuhan Yang Maha Esa agar di beri tuntunan, kesehatan dan terhindar dari marabahaya. Selain itu, membiaskan dan memberikan teladan kepada anak tentang nilai-nilai relegius dalam kehidupan sehari-hari, seperti: bersembahyang, jujur, bersyukur, dan toleransi.

Pengimplemntasian nilai-nilai religius dalam kehidupan sehari-hari secara konsisten dan berkesinambungan akan membentuk sebuah kebiasaan. Pembiasaan adalah sebuah cara yang dilakukan untuk membiasakan anak agar berfikir, bersikap, dan bertindak sesuai dengan tuntunan ajaran agama. Pembiasaan merupakan proses pembentukan sikap dan perilaku yang relatif menetap melalui proses pembelajaran yang berulang-ulang. Pembiasaan mendorong dan memberikan ruang kepada anak pada teori-teori yang membutuhkan aplikasi langsung, sehingga teori yang pada mulanya berat menjadi lebih ringan bagi anak bila seringkali dilaksanakan.

\section{Menumbuhkan Nilai Karakter Disiplin}

Disiplin merupakan sebuah tindakan yang menunjukkan perilaku tertib dan patuh pada berbagai ketentuan dan peraturan. Saat ini, banyak yang meyakini dengan memiliki kedisiplinan tingga berpengaruh terhadap kehidupan seseorang dalam mewujudkan cita-citanya. Selain itu, displin juga di padang sebagai cerminan budaya suatu bangsa. Menurut Kurniwan, (2013) menjelaskan bahwa bangsa yang memiliki peradaban dan budaya yang tinggi memiliki tingkat kedisiplinan yang tinggi. Disiplin terbentuk melalui proses tingkah laku yang menunjukan nilai ketaatan, kepatuhan, kesetiaan, keteraturan dan ketertiban.

Di masa pandemi seperti sekarang ini, tingkat kedisiplinan masyarakat tengah diuji karena untuk memutus mata rantai penularan Virus Covid-19 ini di butuhkan kedisiplinan masyarakat untuk selalu menerapkan protokol kesehatan yang dianjurkan pemerintah. Dari hasil Kuesioner yang diisi dalam aplikasi Google Form yang telah sebar melalui grup WhatsApp orang tua siswa, sebanyak 187 orang dari 219 responden menyatakan bahwa sikap disiplin memiliki arti penting bagi diri sendiri dan orang lain. Pengembangan sikap disiplin pada anak di masa pandemi ini adalah dengan mengikuti protokol kesehatan, seperti: (1) selalu menggunakan masker. Saat ini, menggunakan masker saat berada di luar rumah atau berinteraksi dengan orang lain menjadi hal yang wajib dilakukan, dan sudah menjai kebiasaan. Bahkan di 
beberapa daerah mewajibakan semua orang menggunakan masker jika berada di daerah tersebut, jika tidak akan diberi sanksi tegas. (2) Membudayakan mencuci tangan dengan sabun di air yang mengalir atau menggunakan hand sainitazer ketika akan menyentuh wajah. Dalam upaya membudayakan mencuci tangan, anak-anak di ajarkan cara mencuci tangan yang benar dan menugaskan siswa membuat sebuah vidio cara mencucitangan yang benar. (3) Menjaga jarak 1 sampai 1,5 Meter, hal ini guna menghidari kerumunan banyak orang. (4) Selalu menjaga imunitas tubuh dengan makan-makanan yang bergizi seimbang dan berolah raga secara teratur.

Dalam pembentukan karater disiplin pada anak terdapat tiga prinsip yang perlu diperhatikan, yaitu: (1) kesadaran diri sendiri dari anak tentang pentingnya sebuah kedisiplinan, (2) Keteladanan dari orang tua, guru dan masyarakat, (3) penegakan peraturan yang telah di buat. Keteladanan dan penegakan peraturan merupakan faktor dari luar yang tidak akan bertahan lama bila tidak diikuti dengan komitmen dari kesadaran diri sendiri dalam penegakan kedisiplinan. Menurut Nizar (2009) menyatakan kedisiplinan dapat membentuk kejiwaan anak untuk memahami peraturan sehingga diapun memahami kapan saat yang tepat untuk melaksankan peraturan dan kapan dapat mengesampingkannya. Dalam keseharian anak peraturan selalu ada, sehingga kondisi kejiwaan anak butuh diatur agar kehidupannya tentram.

\section{Menumbuhkan Nilai Karakter Kreatif}

Menurut Kurniawan (2013), Kreatif adalah sebuah kinerja. Kinerja dalam mewujudkan ide dan gagasan melalui serangkaian kegiatan intensif untuk menghasilkan sebuah karya cipta. Karya cipta yang berupa gagasan, kegiatan, karya artefak, sampai performa yang memiliki keunikan khusus yang menarik minat banyak orang. Sejalan dengan itu, Listyarti (2013) mengungkapkan Kreatif merupakan cara berpikir dan melakukan sesuatu untuk menghasilkan cara atau hasil baru dari sesuatu yang telah dimiliki. Menumbuhkan nilai karater kreatif pada anak sejak dini akan menjadikan anak menjadi pribadi yang ulet.

Pemberian tugas pembelajaran yang berbasis masalah dapat merangsang kreatifitas anak. Berdasarkan hasil wawancara dengan beberapa guru SD di Kecamatan Marga, terungkap kekaguman guru melihat hasil karya siswa yang penuh denga kreatifitas. Sebagai contoh, siswa ditugaskan membuat vidio pendek tentang memaknai hari Hari Karini, siswa begitu kreatif mulai dari menyusun sekenario, 
pengambilan tempat syuting, penggunaan ornamen dan editing vidionya. Selain itu, Dari hasil Kuesioner yang diisi dalam aplikasi Google Form yang telah sebar melalui grup WhatsApp orang tua siswa, sebanyak 179 orang dari 219 responden menyatakan sikap kreatif memiliki arti penting dalam kehidupan anak. Berdasarkan hal tersebut orang tua merasa perlu memberikan perhatian dan memotivasi anaknya untuk berkreasi, serta memberi dukungan dengan memantau perkembangan kreatifitas anaknya.

Kreatifitas merupakan salah satu keterampilan yang dibutuhkan pada abad 21, sehingga perlu di kembangkan sejak dini. Pada masa pandemi covid-19 ini merupakan momentum untuk mengembangkan kreatifitas sesuai dengan minat dan bakat anak. Menurut Samani dan Haryanto (2012), terdapat indikator-indikator yang dapat digunakan sebagi acuan untuk pembentukan karakter kreatif pada anak, yaitu: (1) Menampilkan sesuatu secara unik dan menampilkan ide baru. (2) Berani mengambil keputusan dengan cepat dan tepat.(3) Ingin terus berubah dan memanfaatkan peluang baru. (4) Mampu menyelesaikan masalah secara inovatif, luwes dan kritis.

\section{Menumbuhkan Nilai karakter mandiri,}

Nilai karakter mandiri merupakan sikap dan perilaku tidak bergantung pada orang lain dan mempergunakan segala tenaga, pikiran, waktu untuk merealisasikan harapan, mimpi dan cita-cita. Menurut Kemdikbud (2017) menyebutkan anak yang mandiri memiliki etos kerja yang baik, tangguh, berdaya juang, profesional, kreatif, keberanian, dan menjadi pembelajar sepanjang hayat.

Berdasarkan hasil kuesioner yang diisi dalam aplikasi Google Form yang telah sebar melalui grup WhatsApp orang tua siswa, sebanyak 182 orang dari 219 responden menyadari bahwa sikap mandiri penting dalam kehidupan anaknya. Selama kegiatan pembelajaran di rumah, orang tua siswa menyatakan anaknya di biasakan mengejarkan hal-hal sederhana secara mandiri, mulai dari anak bangun tidur untuk merapikan tempat tidur, mandi sendiri dan mengambil makanan. Diawal di berlakukannya pembelajara jarak jauh tugas yang di berikan oleh guru di rumah belum mampu dilakukan sepenuhnya secara mandiri oleh anak, dan seringkali memerlukan bantuan orang tuanya. Hal ini tidak terlepas dari pembelajaran di sekolah selama ini yang cendrung mengandalkan pembelajaran konvensional yang tidak dapat membantu mengembangkan sikap kemandirian anak. Namun setelah berlangsung 
beberapa minggu masa pandemi ini, anak mulai belajar secara mandiri untuk mengerjakan tugas-tugas yang diberikan padanya. Hal ini terlihat dari kemampuan anak-anak membuat sebuah vidio yang temanya di tentukan gurunya. Anak-anak begitu antusias dan kraeatif mengedit vidio tersebut, sehingga menghasilakn karya yang sesuai dengan keinginannya.

Asmani (2011) berpendapat bahwa tujuan pendidikan karakter mandiri adalah penanaman nilai-nilai kemandirian dalam diri siswa dan pembaruan tata kehidupan bersama yang lebih menghargai kebebasan individu. Senada dengan pendapat tersebut, Selain itu, Hasan (Zubaedi, 2011:18) menyatakan bahwa pendidikan karakter mandiri secara perinci memiliki lima tujuan. Pertama, mengembangkan potensi $\mathrm{kalbu} /$ nurani/afektif peserta didik sebagai manusia dan warga negara yang memiliki nilai-nilai karakter bangsa. Kedua, mengembangkan kebiasaan dan perilaku peserta didik yang terpuji dan sejalan dengan nilai-nilai universal dan tradisi budaya bangsa yang memiliki hak mengatur diri sendiri dengan tujuan menjaga ketertiban umum. Ketiga, menanamkan jiwa kepemimpinan dan tanggung jawab peserta didik sebagai generasi penerus bangsa. Keempat, mengembangkan kemampuan peserta didik menjadi manusia yang bertanggungjawab, kreatif, dan berwawasan kebangsaan. Kelima, mengembangkan lingkungan kehidupan sekolah sebagai lingkungan belajar yang aman, jujur, penuh kreativitas dan persahabatan, dan dengan rasa kebangsaan yang tinggi dan penuh kekuatan (dignity).

\section{Nilai karakter tanggung jawab}

Tanggungjawab merupakan perwujudan dari integritas yang dimiliki seseorang. Said Hamid Hasan, dkk (2010) menyatakan bahwa deskripsi tanggung jawab adalah Sikap dan perilaku seseorang untuk melaksanakan tugas dan kewajibannya, yang seharusnya dia lakukan, terhadap diri sendiri, masyarakat, lingkungan (alam, sosial dan budaya), negara dan Tuhan Yang Maha Esa. Dalam kegiatan pembelajaran di rumah, pembentukan sikap tanggung jawab pada anak diawali dengan membangun kesadaran anak bahwa mereka mesti bertanggung jawab dalam setiap hal termasuk ketika diberikan tugas rumah, maka mereka harus mengerjakannya.

Berdasarkan hasil kuesioner yang diisi dalam aplikasi Google Form yang telah sebar melalui grup WhatsApp orang tua siswa, sebanyak 178 orang dari 219 responden menyadari bahwa pentingnya menumbuhkan nilai karakter beratnggung jawab 
kepada anak. Salah satu bentuk kegiatan yang dilakukan guru dalam menumbuhkan sikap tanggung jawab pada anak adalah dengan membuat atuaran tentang riward dan punishment dalam menilai pengerjaan tugas yang diberikan. Pemberian reward kepada peserta didik yang mengerjakan dan memberikan punishment kepada peserta didik yang tidak mengerjakan pekerjaan rumah, serta pemberian nilai yang dibedakan antara yang mengumpul tepat waktu dan yang telat sehingga anak merasa bertanggung jawab dalam pekmberian tugas rumah tersebut dan yang mengerjakan merasakan keadilan. Selain itu, selama belajar di rumah anak dibiaskan untuk bertanggung jawab terhadap tugas yang mereka kerjakan hingga selesai.

Pengembangan pendidikan karakter adalah suatu proses penerapan nilai-nlai moral dan agama pada peserta didik melalui ilmu-ilmu pengetahuan, penerapan nilainilai tersebut baik terhadap diri sendiri, keluarga, sesama teman, terhadap pendidik dan lingkungan sekitar maupun Tuhan Yang Maha Esa. Secara harfiah, peran partisipatif orang tua berarti peran serta/partisipasi orang tua (termasuk keluarga) secara aktif dalam mendukung pendidikan siswa/anaknya. Permendikbud Nomor 30 Tahun 2017 tentang Pelibatan Keluarga Pada Penyelenggaraan Pendidikan mengatur bahwa salah satu tujuan pelibatan keluarga pada penyelenggaraan pendidikan adalah membangun sinergitas antara satuan pendidikan, keluarga, dan masyarakat. Pendidikan yang bersinergi diyakini mampu menumbuhkan hal-hal positif yang berkaitan dengan karakter maupun hasil belajar. Sejalan dengan itu, Ki Hajar Dewantara (dalam Kemdikbud, 2017) menyatakan keberhasilan pendidikan sangat ditentukan oleh keluarga, mengingat dalam keluargalah pondasinya dibangun sehingga keluarga juga bisa disebut pusat pendidikan. Inilah sinergi pendidikan yang diidamkan, di mana antara sekolah dapat bermitra erat dengan orang tua siswa.

Pada pandemi ini orang tua memiliki peran cukup besar terhap keberhasilan pengembangan nailai-nilai karakter di rumah. Pada masa pandemi covid-19 ini intensitas komunikasi orangtua dan anak sangat tinggi. Dalam pngembangan nilainilai karakter di rumah, orang tua berperan sebagai fasilitator yang membantu anak untuk pengembangan karakter secara efektif. Orang tua juga harus mampu bertindak sebagai filterasi yang membantu anak menyaring berbagai pengaruh negatif yang berdampak tidak baik bagi perkembangannya. Orang tua juga mampu berperan sebagai penghubung anak dengan berbagai sumber-sumber belajar yang dekat dengan 
lingkungannya sehari-hari. Dan orang tua juga berperan sebagai katalisator, agar mampu menggali dan mengoptimalkan potensi yang dimiliki oleh anak.

Kolaborasi anatara guru, orang tua dan anak dalam pembelajaran jarak jauh pada masa pandemi covid-19 merupakan sebuah aselerasi menuju pembentukan kecakapan abad 21. Selain itu, kolaborasi tersebut menjadi sebuah komposisi pembelajaran yang sangat ideal, karena setting pembalajaran yang diterapkan mampu mengintegrasikan pengetahuan, keterampilan dan sikap serta penguasaan TIK yang di miliki siswa dalam membuat sebuah karya. Terbentuk nilai karakter dominan dalam penelitian ini, seperti: sikap relegius, disiplin, kreatif, madiri dan tanggung jawab, tidak terlepas dari pembelajaran yang dilakukan. Pembelajran yang dikembangkan, selalu mengupayakan beberapa hal sebagi berikut. (1) Kecakapan Berpikir Kritis dan Pemecahan Masalah (Critical Thinking and Problem Solving Skill; (2) Kecakapan Berkomunikasi (Communication Skills); (3) Kecakapan Kreatifitas dan Inovasi (Creativity and Innovation); dan (4) Kecakapan Kolaborasi (Collaboration).

Kegiatan positif yang dilakukan dirumah secara bersama-sama akan membentuk sebuah ikatan emosial yang baik antara anak dan orang tua. Sebuah chemistry yang akan mucul selama melakukan kegiatan bersama-sama, menumbuhkan cinta yang nantinya menjadi sebuah kebiasaan (habbit) (Ratminingsih, 2019). Konsep ini sebenarnya sangat bagus diterapkan di lingkungan keluarga dengan membiasakan nilai-nilai karakter yang positif di dalam setiap aktivitas bersama (Komalasari \& Saripudin, 2017). Sehingga nantinya model ini dapat berjalan secara terus menrus sampai ketika nanti pandemi COVID-19 ini berakhir pola ini tetap berlangsung. Ini merupakan momentum yang baik bagi pendidikan karakter dari rumah.

\section{Kesimpulan}

Pandemi Covid-19 saat ini telah mentrasformasi sebagian besar kehidupan masyarakat. Selama ini, pendidikan karakter yang terkesan stagnan dan baru pada tatanan konsep, kini bergeser menjadi pembiasaan (habbit). Pembentukan Karakter menjadi sebuah kebiasaan apabila aktivitas penanaman nilai-nilai karakter dilakukan berulang-ulang secara rutin hingga menjadi suatu kebiasaan, yang akhirnya tidak hanya menjadi suatu kebiasaan saja tetapi sudah menjadi suatu karakter. Pengembangan nilai-nilai karakter pada anak akan sangat efektif jika melibatkan oarang tua dan kelurga. Di masa pandemi Covid-19 saat ini, kolaborasi peran 
keluarga, guru dan masyarakat sekitar sangatlah penting dalam mengembangkan nilai-nilai karakter anak. Keluarga sebagai tempat utama dan pertama peserta didik menjalani kehidupan hendaklah mengawasi dan membimbing dengan penuh kasih sayang, tegas, dan cermat. Pada masa pandemi ini anak tidak hanya diajarkan tentang konsep niali-nilai karakter yang baik, tetapi bagaimana mengarahkan anak untuk dapat mengimplementasikan pada kehidupam sehari-hari.

Dalam penelitian ini, diperoleh data bahwa nilai-nilai karakter yang diberkembang orang tua pada anak di masa pandemi Covid-19 di TK dan SD SeKecamtan Marga adalah (1) Nilai karakter religius, (2) Nilai karakter disiplin, (3) Nilai karakter kreatif, (4) Nilai karakter mandiri, (5) Nilai karakter tanggung jawab, dan (6) Nilai karakter rasa ingin tahu. Pengembangan nilai-nilai karakter tersbut, tentu perubahan yang sangat luar biasa dalam hal pengembangan karakter anak. Keberhasilan dari pengembangan nilai karakter pada anak tersebut tidak terlepas dari peran guru dan orang tua untuk mau bertransformasi agar dapat dijadikan sebagai panutan penerapan karakter yang baik pada diri sendiri. Inilah momentum pendidikan karakter di lingkungan keluarga. Dengan harapan sampai pandemi ini berakhirpun pola pendidikan karakter di lingkungan keluarga ini tetap berlangsung.

\section{Daftar Pustaka}

Abdusshomad, A. (2020). Pengaruh Covid-19 terhadap Penerapan Pendidikan Karakter Dan Pendidikan Islam. QALAMUNA: Jurnal Pendidikan, Sosial, dan Agama 12(2), 107115.

Ahmadi F., Yusef. (2017). Pembelajaran Wacana Sebagai Ladasan dalam Berliterasi Sastra untuk Meningkatkan Karakter Siswa. Prosiding SENASBASA (Seminar Nasional Bahasa dan Sastra). Edisi 1.

Anwar, A. (2013). Kontribusi Keluarga terhadap Pembentukan Karakter Anak (Studi Perspektif Modal Sosial di Kota Parepare). Kuriositas: Media Komunikasi Sosial dan Keagamaan. 9(1). 57-65.

Asmani, Ma'mur Jamal. 2011. Buku Panduan Internalisasi Pendidikan karakter di Sekolah. Yogyakarta: Diva Press

Chan, J. F., Yuan, S., Koh, K. H., To, K. K., Chu, H., Yang J., .. Yuen, K. Y. (2020). A Familial Cluster of Pneumonia Associated with The 2019 Novel Coronavirus Indicating 
Person-To-Person Transmission: A Study Of Family Cluster. Lancet. 395(10223):514523.

Dalyono, B., Lestariningsih, E. D. (2016). Implementasi Penguatan Pendidikan Karakter di Sekolah. Bangun Rekaprima: Majalah Ilmiah Pengembangan Rekayasa, Sosial dan Humaniora 3(2), 33-42.

Diana, P. Z., Wirawati, D., Rosalia, S. (2020). Blended learning dalam pembentukan kemandirian belajar. Alinea: Jurnal Bahasa, Sastra, dan Pengajaran 9(1), 16-22, 2020.

Fraenkel, J. R., Wallen, N. E. (2008). Introduction to Qualitative Research: How to Design and Evaluate Research in Education, $7^{\text {th }}$ ed. Boston, MA: McGraw-Hill.

Gerring, J. (2007). Case Study Research: Principles and Practices. New York: Cambridge University Press.

Ghinai, I., McPherson, T. D., Hunter, J. C., Kirking, H. L, Christiansen, D., Joshi, K., ... Layden, J. E.: Illinois COVID-19 Investigation Team. (2020). First known person-toperson transmission of severe acute respiratory syndrome coronavirus 2 (SARS-CoV-2) in the USA. Lancet. pii: S0140-6736(20)30607-3.

Hamid, H., Said. (2010). Baham Pelatihan Penguatan Metodologi Pembelajraan Berdasarkan Nilai-Nilai Budaya untuk Membentuk Daya Saing dan Karakter Bangsa Pengembangan Pendidikan Budaya dan Karakter Bangsa, Jakarta: Kementrian Pendidikan Nasional Badan Penelitian dan pengembangan Pusat Kurikulum.

Heigham, J., Croker, R. A. (2009). Qualitative Research in Applied Linguistics: A Practical Introduction. London: CPI Antony Rowe, Chippenham and Eastbourne.

Hulukati, W. (2015). Peran Lingkungan Keluarga terhadap Perkembangan Anak. Jurnal Musawa IAIN PALU, 7(2), 265-282.

Isbaniah, F., Kusumowardhani, D., Sitompul, P. A., Susilo, A., Wihastuti, R., Setyawati, V., ... Kamal, M. (2020). Pedoman pencegahan dan pengendalian coronavirus disease (COVID-19). Direktorat Jendral Pencegahan dan Pengendalian Penyakit. Kementerian Kesehatan. Jakarta.

Kementerian Pendidikan Kebudayaan Republik Indonesia. (2017). Peraturan Menteri Pendidikan dan Kebudayaan RI Nomor 30 Tahun 2017 tentang Pelibatan Keluarga Pada Penyelenggaraan Pendidikan. Jakarta: Kementerian Pendidikan dan Kebudayaan.

Kementerian Pendidikan Kebudayaan Republik Indonesia. (2017) Penguatan Pendidikan Karakter Jadi Pintu Masuk Pembenahan Pendidikan Nasional. 
tersedia di halaman web. https://www.kemdikbud.go.id/main/ blog/2017/07/penguatan-pendidikan-karakter-jadi-pintu-masuk-pembenahanpendidikan-nasional. Diunduh Tanggal 21 Mei 2020

Kementerian Pendidikan dan Kebudayaan Republik Indonesia. 2020. Surat Edaran Nomor 4 tahun 2020 Tentang Pelaksanaan Pendidikan dalam Masa Darurat Covid-19. https://kemdikbud.go.id/main/blog/2020/03/mendikbud-terbitkanse-tentang-pelaksanaan-pendidikan-dalam-masa-darurat-covid-19. Diakses 30 Maret 2020.

Komalasari, K., Saripudin, D. (2017). Pendidikan Karakter: Konsep dan Aplikasi Living Values Education. Bandung. PT Refika Aditama.

Kurniawan, S. (2013). Pendidikan Karakter, Konsepsi \& Implementasinya secara Terpadu di Lingkungan Keluarga, Sekolah, Perguruan Tinggi dan Masyarakat. Yogyakarta : ArRuzz Media. Hlm. 136

Kurniawan, S. (2013). Pendidikan Karakter.Yogyakarta: Ar-Ruzz Media.

Kusuma, D. A. (2010). Pendidikan Karakter Strategi Mendidik Anak di Zaman Grobal. Jakarta: Grasindo.

Lickona, T. (2012). Educating for Character; Mendidik untuk Membentuk Karakter. Jakarta: Bumi Aksara.

Listyarti, Retno. 2013. Pendidikan Karakter dalam Metode Aktif, Inovatis, E Kreatif. Jakarta: Erlangga.

Moleong, L. J. (2013). Metodologi Penelitian Kualitatif. Bandung: PT. Remaja Rosdakarya Offset.

Muslikhin (2019). Nilai-nilai Pendidikan Karakter dalam Pembelajaran Pendidikan Agama Islam. Al-Bahtsu: Jurnal Penelitian Pendidikan Islam 4(1).

Nazerly, M. K. (2020). Implementasi zoom, google classroom, dan whatsapp group dalam mendukung pembelajaran daring (online) pada mata kuliah Bahasa Inggris Lanjut (Studi kasus pada 2 kelas semester 2, Jurusan Administrasi Bisnis, Fakultas Ekonomi dan Bisnis, Universitas Bina Sa. Aksara Publik, 4(2), 155-156.

Nizar, Imam Ahmad Ibnu. 2009. Membentuk E Meningkatkan Disiplin Anak Sejak Dini. Yogyakarta : DIVA Press.

Nunan, D. (1992). Research Method in Language Leraning. New York. Cambridge University Press. 
Peraturan Menteri Pendidikan dan kebudayaan Republik Indonesia Nomor 20 Tahun 2018. Penguatan Pendidikan Karakter pada Satuan Pendidikan Formal. Kementerian Pendidikan Kebudayaan. 7 Juni 2018. Lembaran Negara Republik Indonesia Tahun 2018 Nomor 194.

Peraturan Presiden Nomor 87 Tahun 2017. Penguatan Pendidikan Karakter. Kementerian Hukum dan Ham. 6 September 2017. Lembaran Negara Republik Indonesia Tahun 2017 Nomor 195.

Prasetiawan, H. (2016). Peran Bimbingan dan Konseling dalam Pendidikan Ramah Anak terhadap Pembentukan Karakter Sejak Usia Dini. Jurnal CARE (Children Advisory Research and Education) 4(1), 50-60.

Ratminingsih, N. M. (2019). Pengajaran, Karakter, dan Cinta. Singaraja. Mahima Institute Indonesia.

Roulston, K. (2018). Triangulation in Qualitative Research. QualPage. Diakses 1 Juni 2020. https://qualpage.com/2018/01/18/triangulation-in-qualitative-research/

Ruyadi, Y. (2010). Model Pendidikan Karakter berbasis Kearifan Budaya Lokal: Penelitian terhadap Masyarakat Adat Kampung Benda Kerep, Cirebon, Provinsi Jawa Barat untuk Pengembangan Pendidikan Karakter. Proceeding of The $4^{\text {th }}$ International Conference on Teacher Education, 577-595.

Samani, Muchlas dan Hariyanto. 2012. Konsep dan Model Pendidikan. Bandung: PT Remaja Rosdakarya.

Saxena, S. K. 2020. Coronavirus Diseas 2019 (COVID-19): Epidemoogy, Pathogenis, Diagnosis, and Therapeutics. Singapore. Springer Pte Ltd.

Sekretaris Kabinet Republik Indonesia. 2020. Dasar Hukum Penanganan COVID-19. Laman Sekretaris Kabinet Republik Indonesia. https://setkab.go.id/?s=Dasar+hukum+penanganan+covid\&lang=id. Diakses 4 Mei 2020.

Sudrajat, A. (2011). Mengapa Pendidikan Karakter. Jurnal Pendidikan Karakter, 1(1), 47-58. Suharyanto. 2020. Kumpulan Peraturan Perundangan Undangan tentang Covid 19. Jakarta. Ikatan Pustakawan Indonesia.

Supranoto, H. (2015). Implementasi Pendidikan Karakter Bangsa dalam Pembelajaran SMA. Jurnal Promosi 3(1), 36-49.

Syarbini, A. (2014). Model Pendidikan Karakter dalam Keluarga. Jakarta. PT. Elex Media Komputindo. 
Teguh, M. (2015). Difusi Inovasi dalam Program Pembelajaran Jarak Jauh di Yayasan Trampil Indonesia. Lembaga Penelitian dan Pengabdian Kepada Masyarakat Universitas Kristen Petra, 2015. https://dspace.uc.ac.id/handle/123456789/907

Tim Kerja Kementerian Dalam Negeri. 2020. Pedoman Umum Menghadapi Pandemi COVID-19 Bagi Pemerintah Daerah; Pencegahan, Pengendalian, Diagnosis dan Manajemen. Kementerian Dalam Negeri Republik Indonesia. Jakarta.

World Health Organization. (2020a). Coronavirus Diseas 2019 (COVID-19). Situation Report-85 World Health Organization. https://www.who.int/docs/defaultsource/coronaviruse/ situation-reports/20200414-sitrep-85-covid19.pdf?sfvrsn=7b8629bb_4. Diakses 18 April 2020.

World Health Organization. (2020b). Public Statement for Collaboratiion on COVID-19 Vaccine Development. News Room. World Health Organization. https://www.who.int/news-room/ detail/13-04-2020-public-statement-forcollaboration-on-covid-19-vaccine-development. Diakses 15 Mei 2020.

Wulandari, Y., Kristiawan, M. (2017). Strategi Sekolah dalam Penguatan Pendidikan Karakter bagi Siswa dengan Memaksimalkan Peran Orang Tua. JMKSP (Jurnal Manajemen, Kepemimpinan, dan Supervisi Pendidikan) 2(2).

Zhou, W. (2020). Buku panduan pencegahan coronavirus: 101 tips berbasis sains yang dapat menyelamatkan hidup anda. Fin e-book. https:/ / fin.co.id

Zubaedi. (2011). Desain Pendidikan Karakter: Konsep dan Aplikasinya dalam Lembaga Pendidikan. Jakarta: Kencana. 